\title{
Paget's Disease Diagnosed on Cranial and Sacroiliac Involvement in Contrast to Normal Alkaline Phosphatase Levels
}

\author{
Kraniyal ve Sakroiliak Tutulum ile Tanı Konulan Alkalen Fosfatazın Normal Olduğu Paget \\ Hastalığı
}

(D) Gonca Sağlam

Erzurum Regional Training and Research Hospital, Clinic of Physical Therapy and Rehabilitation, Erzurum, Turkey

\section{Abstract}

Paget's disease of bone is characterized by a chronic focal bone remodelling disorder, which is usually detected incidentally during routine imagining examinations. Although the measurement of total serum alkaline phosphatase usually provides a general indication of bone turnover in Paget's disease, about 10-15\% of patients present with alkaline phosphatase levels within the normal range. The treatment of symptomatic forms relies on bisphosphonates that are efficient in reducing the bone turnover. Here, I present the case of an 80-year-old man suffering from chronic low back pain, and diagnosed as Paget's disease, with normal serum alkaline phosphatase and bone-specific alkaline phosphatase levels.

Keywords: Paget's disease, alkaline phosphatase, bone scintigraphy

\section{Öz}

Kemiğin Paget hastalığı, genellikle radyolojik incelemelerde tesadüfen tespit edilen kronik fokal kemik yapılanma bozukluğu ile karakterizedir. Her ne kadar serum total alkalen fosfataz Paget hastalığında genel bir kemik döngüsü belirteci olsa da, hastaların yaklaşık \%10-15'inde referans aralığında bulunur. Semptomatik formların tedavisi, kemik döngüsündeki yükselmeleri azaltmakta etkili olan bifosfonatlar ile sağlanır. Burada kronik bel ağrısı olan ve normal serum alkalen fosfataz ve kemik spesifik alkalen fosfataz düzeyleri ile Paget hastalığı tanısı alan 80 yaşında bir olgu sunulmaktadır.

Anahtar kelimeler: Paget hastalığı, alkalen fosfataz, kemik sintigrafisi

\section{Introduction}

Paget's disease of bone (PDB) is a nonmalignant, chronic and focal skeletal disorder that mainly presents in elderly population and is the second most common metabolic bone disease after osteoporosis affecting individuals. Although the etiology of Paget's disease is enigmatic, the role of viruses (paramyxovirus and measles) and genetics remain debated in the literature. It is more common in European ancestry and man is affected more as compared to woman (1-3).

Paget's disease begins with an increase in osteoclastic bone resorption, followed by an increase in osteoblastic activity and consequently lamellar bone formation in the mosaic structure. Normal bone structure is replaced by disorganized, hypertrophic and weak bone nature that is more fibrous and less dense with irregular trabecular pattern. It usually effects the bones focal (monostotic), but diffuse involvement (polyostotic) can also be seen depending on the number of bone involved. There may be involvement of almost every bone but there is a predilection for some skeletal sites (pelvis, spine, sacrum, skull, femur and tibia) $(4,5)$.

\section{Case Report}

An 80-year-old male patient complained of a low back pain for the last 4 years and 8 weight loss in the last 3 months. His pain did not change with the movement and continued at night. No fever was detected while sweating accompanied by night pain. He had hypertension for 20 years and memory loss for a year. There was no history of diabetes, tuberculosis, malignancy, inflamatory arthritis or any other significant diseases. He also stated that he had taken calcium and vitamin D for a few months. On physical examination, the patient had kyphosis of the back, movements in the spine were limited

Address for Correspondence/Yazışma Adresi: Gonca Sağlam MD, Erzurum Research Training and Rehabilitation Hospital, Clinic of Physical Therapy and Rehabilitation, Erzurum, Turkey

Phone: +90 5054525688 E-mail: goncasaglam@hotmail.com ORCID ID: orcid.org/0000-0001-7713-4435 Received/Geliş Tarihi: 12.09.2019 Accepted/Kabul Tarihi: 08.11.2019

${ }^{\circ}$ Copyright 2020 by the Turkish Osteoporosis Society / Turkish Journal of Osteoporosis published by Galenos Publishing House 
and painful. Direct compression of the sacroiliac joint on the left was positive while other joint evaluations were normal. Some of her blood tests were: serum alkaline phosphatase (ALP): 78 (40-150) ) U/L, 25-hydroxy-vitamin D3: 156.5 (1060) $\mu \mathrm{g} / \mathrm{L}$, bone-specific ALP: 21.0 (3.10- 22.40) $\mu \mathrm{g} / \mathrm{L}$, urinary deoxypyridinoline: $8.05 \mathrm{nM} / \mathrm{mM}$ creatinine ratio and brucella agglutination test was negative. Other laboratory evaluations, parathyroid and thyroid hormone levels, calcium and tumor marker levels were normal but blood urea and creatinine levels were slightly elevated.

Cranial X-rays showed diffuse sclerosis and calvarial thickening while pelvic radiography revealed sclerosis of the left sacroiliac joint (Figure 1). No pathology was observed on chest X-ray. Magnetic resonance imaging showed sacroiliac involvement as signal changes resembling degeneration on the iliac side. The patient's bone scintigraphy was performed by administering 20 millicurie of Technetium 99m-methylene diphosphonate intravenously and demonstrated involvement in the left hemipelvic region and left area of the cranium. Screening for possible malignancy with positron emission tomography and abdominal tomography did not revealed any primaly tumor. Although serum ALP and bone-specific ALP levels were normal, imaging studies of the patient were mainly compatible with PDB. Since urea and creatinine levels were slightly elevated, the patient's treatment started with hydration and renal functions improved during follow-up. The patient underwent zoledronic acid $5 \mathrm{mg} / 100 \mathrm{~mL} /$ year single dose infusion therapy with creatine clearance of 32 . The patient's complaints regressed and he was discharged with recommendations. The pagetic lesions achieved marked improvement after 6 months and outpatient follow-up was uneventful for a year. Written informed consent was obtained from the patient for publication of this case report.

\section{Discussion}

Paget's disease of the bone is seen in 3-3.7\% of patients over 40 years of age, which can cause complications such as chronic bone pain, skeletal deformities, heart failure and cranial nerve compressions, so early diagnosis is prominent. While the majority of patients are asymptomatic, the most common symptom is bone pain in Paget's disease which is typically worse at rest (6). Depending on the involvement, patients mostly complain of low back and hip pain. Sacroiliac joint involvement can be seen rarely in PDB and differantial diagnosis of spondyloarthritis should be considered in these cases (7). Possible complications include hearing loss, basilar invagination of skull, obstructive hydrocephalus, spinal canal stenosis and paraplegia. The presenting complaint was spinal pain in our patient. Pathological fractures, neurological or auditory problems were not detected.

ALP is an enzyme which is synthesized by osteoblasts and made mostly in liver and bone. It is associated with mineralization of bone and represents an effective biochemical marker of bone formation. Compared with various bone derivied diseses, the highest serum ALP level is observed in Paget's disease. which is caused by osteoblasts action following bone destruction by the uncontrolled activity of osteoclasts (8). It is also a sensitive screening marker for PDB and is helpful in monitoring the treatment response. Although blood test for ALP is usually elevated in people with PDB which is very important for diagnosis, ALP can be detected in normal levels in 10-15\% of patients as in our case (9). In case of normal serum ALP levels, bone-specific ALP levels are elevated in 60\% and urinary pyridinoline is increased in $40 \%$ of the patients in PDB (10). The fact that other markers of bone formation and destruction are within normal limits can be explained by disease of limited extend in two regions and the previous use of bisphosphonate in our patient (11).

In our case, sacroiliac joint sclerosis and cortical thickening of the skull which were observed on radiographs were important in diagnosis. Our patient did not meet the clinic or radiographic criteria of spondyloarthritis or other disease that may lead to sacroiliitis.

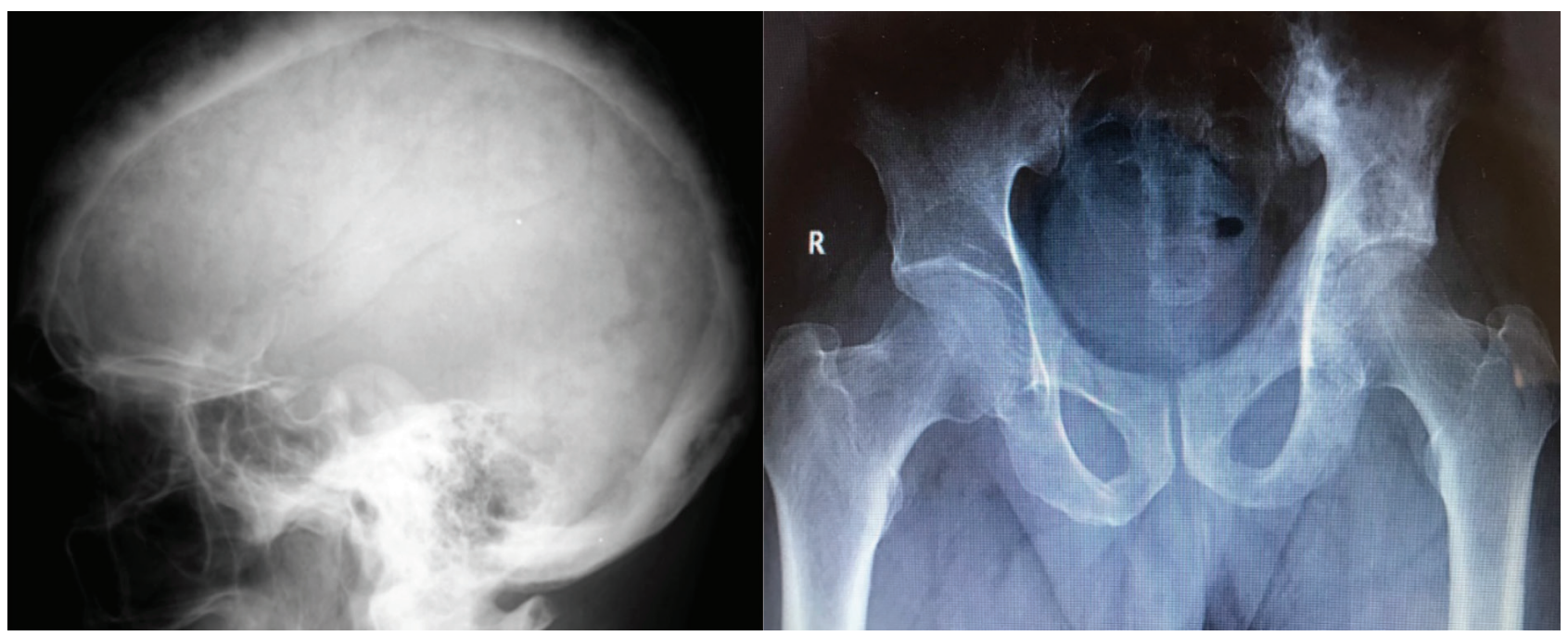

Figure 1. X-rays of cranium and pelvis 
PDB and bone metastases share many common features in terms of pathophysiological changes in bone. Prostate, breast, stomach, bladder and lung cancers may develop osteosclerotic involvement similar to those of PDB. In addition, osteosarcoma, multiple myeloma and lymphoma of primary bone cancers may have osteosclerotic appearance (12).

Therefore, malignancy should be ruled out in the elderly patients with sclerotic lesions. In our patient, tumor markers and imaging methods were screened and no signs of malignancy were detected. Bone scintigraphy is recommended to all patients for differential diagnosis. It showed diffuse increased uptake of isotope by parietal bone of skull and left sacroiliac joint suggestive of PDB in our patient. While bone scintigraphy is widely considered to be the most sensitive method for determining the extend of skeleteal damage and evaluating the scope, X-rays should be taken in all symptomatic areas and it should be kept in mind that osteosarcomatous transformation may ocur which constitutes the most dreaded complication of the disease (13).

Before treatment, the presence of Paget's symptoms and secondary complications should be evaluated. The most common indication for treatment is symptomatic disease that can be featured with bone pain, radiculopathy or arthropathy due to PDB, or other complications. The purpose of medications are supressing the accelerated bone turnover and improving bone pain. The mainstay of medical management involves the use of bisphosphonates since decades which are given after vitamin D replacement $(14,15)$. Oral alendronate or risedronate, intravenous pamidronate or zoledronic acid may be given as they inhibit exaggerated bone turnover and reduces bone loss (13). The recommended treatment by the guideline published by the Endocrine Society is a single dose of intravenous infusion of $5 \mathrm{mg}$ zoledronic acid (16). In literature, zoledronic acid is found to be the most potent agent in decreasing ALP blood level, improving quality of life and preventing relapse. The response to zoledronic acid is also more rapid when compared to oral bisphosphonates and the response is sustained for years $(17,18)$.

Calcitonin also reduces bone resorption by inhibiting osteoclastic activity and provides timely pain relief. It was used for the treatment of PDB previously but is not used anymore due to the relapses and resistances after treatment. Denosumab have also been reported to improve bone pain and decrease total ALP levels but is not licensed for PDB yet. Some studies revealed that denosumab rapidly decrease ALP levels compared to bisphosphonates $(19,20)$.

In addition to bisphosphonate therapy, analgesics can be added for pain management. Non-steroidal anti-inflammatory drugs and anti-neuropathic agents can be useful for pain control. In cases with skeletal deformities, cranial nerve involvement or severe osteoarthritis, surgical intervention is required that includes osteotomy for progressive deformity, fixation of impending fracture, joint arthroplasty and spinal decompression (21).

In this case report, I aimed to emphasize the importance of scintigraphy in early diagnosis of Paget's disease and to indicate that Paget's disease should not be excluded in patients with normal ALP levels in chronic skeletal pain.

\section{Ethics}

Informed Consent: Written informed consent was obtained from the patient.

Peer-review: Internally peer-reviewed.

Financial Disclosure: The author declared that this study received no financial support.

\section{References}

1. Corral-Gudino L, Borao-Cengotita-Bengoa M, Del Pino-Montes J, Ralston SH. Epidemiology of Paget's disease of bone: a systematic review and meta-analysis of secular changes. Bone 2013;55:347-52.

2. Teramachi J, Nagata Y, Mohammad K, Inagaki Y, Ohata Y, Guise $T$, et al. Measles virus nucleocapsid protein increases osteo blast differentiation in Paget's disease. J Clin Invest 2016;126:1012-22.

3. Visconti MR, Usategui-Martin R, Ralston SH. Antibody response to paramyxoviruses in Paget's disease of bone. Calcif Tissue Int 2017;101:141-7.

4. Tuck SP, LayŞeld R, Walker J, Mekkayil B, Francis R. Adult Paget's disease of bone: a review. Rheumatology (Oxford) 2017:56:20509 .

5. Britton C, Brown S, Ward L, Rea SL, Ratajczak T, Walsh JP. The Changing Presentation of Paget's Disease of Bone in Australia, A High Prevalence Region. Calcif Tissue Int 2017;101:564-9.

6. Kelepouris N, Schur PH, Drezner MK, Romain PL. Clinical manifestations and diagnosis of Paget disease of bone. In: UpToDate, Basow,DS (Ed), UpToDate, Waltham, MA, 2010.

7. Bezza A. Sacro-liac involvement in the course of Paget disease. Report of 6 cases. Presse Med 1999;28:1157-9.

8. Roudsari JM, Mahjoub S. Quantification and comparison of bonespecific alkaline phosphatase with two methods in normal and paget's specimens. Caspian J Intern Med 2012;3:478-83.

9. Eekhoff ME, van der Klift M, Kroon HM, Cooper C, Hofman A, Pols HA, et al. Paget's disease of bone in the Netherlands: a populationbased radiological and biochemical survey - the Rotterdam Study. J Bone Miner Res 2004;19;566-70.

10. Alvarez L, Guanabens N, Peris P, Monegal A, Bedini JL, Deulofeu $R$, et al. Discriminative value of biochemical markers of bone turnover in assessing the activity of Paget's disease. J Bone Miner Res 1995;10;458-65.

11. Wu LC, Tseng $\mathrm{CH}$, Chiang YF, Tsuang YH. Monostotic vertebral Paget's disease of the lumbar spine. J Chin Med Assoc 2009;72:52-

12. Skeletal metastases. In: Resnick-Kransdorf, editors. Bone and joint imaging, (3th eds). Elsevier Saunders 2005:1245-64.

13. Bolland MJ, Cundy T. Paget's disease of bone: clinical review and update. Postgrad Med J 2014;90:328-31.

14. Bolland MJ, Cundy T. Paget's disease of bone: clinical review and update. J Clin Pathol 2013;66:924-7.

15. Corral-Gudino L, Tan AJ, Del Pino-Montes J, Ralston SH. Bisphosphonates for Paget's disease of bone in adults. Cochrane Database Syst Rev 2017;12:CD004956.

16. Singer FR, Bone HG 3rd, Hosking DJ, Lyles KW, Murad MH, Reid IR, et al. Paget's disease of bone: an endocrine society clinical practice guideline. J Clin Endocrinol Metab 2014;99;4408-22.

17. Hosking D, Lyles K, Brown JP, Fraser WD, Miller P, Curiel MD, et al. Long-term control of bone turnover in Paget's disease with zoledronic acid and risedronate. J Bone Miner Res 2007;22:1428.

18. Reid IR, Lyles K, Su G, Brown JP, Walsh JP, del Pino-Mortes J, et al. A single infusion of zoledronic acid produces sustained remissions in Paget disease: data to 6.5 years. J Bone Miner Res 2011;26:226170.

19. Reid IR, Sharma S, Kalluru R, Eagleton C. Treatment of Paget's disease of bone with denosumab:case report and literature review. Calcif Tissue Int 2016;99:322-5.

20. Hirao M, Hashimoto J. Denosumab as the potent therapeutic agent against Paget's disease of the bone. Clin Calcium 2011;21;1231-8.

21. Griz L, Caldas G, Bandeira C, Assunção V, Bandeira F. Paget's disease of bone. Arq Bras Endocrinol Metab 2006;50:814-22. 